\title{
Speleogenesis and Evidences Tectonic into Lakhssas Karst System (Western Anti-Atlas, Morocco)
}

\author{
Abderrahmane Wanaim*, Mhamed Alaeddine Belfoul, Sophia Bouzid, Farid Faik \\ GESCAT Laboratory, Faculty of Science, Ibn Zohr University, Agadir, Morocco \\ Email: ${ }^{*}$ a.wanaim@uiz.ac.ma
}

Received 14 May 2014; revised 10 June 2014; accepted 5 July 2014

Copyright (C) 2014 by authors and Scientific Research Publishing Inc.

This work is licensed under the Creative Commons Attribution International License (CC BY).

http://creativecommons.org/licenses/by/4.0/

c) (i) Open Access

\begin{abstract}
This study aims to highlight evidences of tectonic and geodynamic features within Lakhssas high plateau karst area (Moroccan Western Anti-Atlas), using an original approach based on geospeleothems analysis. This work is organized by the speleogenesis process, controlled by tectonics and interference of karst intrinsic parameters. Regarding the first issue, a multi-layered study compiling inventoried speleological spaces with tectonic field data analysis then with lithological, hydrogeological and geomorphological features, has demonstrated that speleogenesis processes are deeply controlled by tectonic framework so described as "speleotects". Subsequent studies in terms of sedimentology, geomorphology, hydrogeology and dating deposits, are planned to ground those conclusions.
\end{abstract}

\section{Keywords}

Geospeleothems Superposed Tectonic, Lakhssas Karst, Anti-Atlas, Uplift

\section{Introduction}

Caves are natural archives that preserve sediments, tectonic motions and paleo-earthquakes for a considerable period [1] and [2]. This work concerns geospeleological approach as an original thematic study used rarely in Morocco, probably in whole Africa to highlight tectonic motions through an endokarstic device.

\footnotetext{
${ }^{*}$ Corresponding author.
} 


\section{Geomorphological and Geological Framework of Lakhssass Karstic Device}

\subsection{Geomorphological Context}

Morocco takes the northwestern corner of the Africain continent and the country represents a mosaic of various geodynamic events from the geological annals of Africa, from the Pre-Cambrian until the present. The favorable conditions here help the preservation of unique paleo and neo karst [3]. Lakhssas area (Moroccan western AntiAtlas) is a flattening surface (plateau) rising up to $2000 \mathrm{~m}$ of altitude overlapping a hercynian complex compression structure [4] [5]. From satellite view, it appears in the shape of a bat: narrow in the middle with about 30 $\mathrm{Km}$ width and elongated over $47 \mathrm{Km}$ length from north to south. It builds a natural bridge between two inliers: Ifni in the west and Kerdous in the east separating the Tiznit basin at north (southern extension of Souss basin), from that of Bouizakarn at south (Figure 1).

Lakhssas plateau is an interesting karstic device that provides a signified diversity of speleothems that refers to all forms of endokarstic environment. Its fascinating underground network constitutes a geological patrimony. It develops groundwater, sink-holes, lapiez and dry conditioning systems; typical forms of karstic areas that are excellent markers of neotectonic and seismic activities but also useful to interpret paleoclimate.

It is considered as prehamadian lands surrounded by wide dolomitic and calcareous adoudounian outcrops [6].

\subsection{Geological Setting}

Lakhssas outcrops belong to the western Anti-Atlas. It exhibits a Neoproterozoic and Palaeozoic sedimentary cover [7], dominated by Adoudounian (terminal Proterozoic) and Georgian (lower Cambrian) limestones and dolomites (Figure 2). Those integuments surround Precambrian inliers with the most closers are from SW to NE: Ifni, Kerdous, Ighrem. The main structures are of hercynian orogeny network: submeridionale verticale faults associated to wide folds such as those of Jbel Inter north and south of Id Yahia. During this time, Lakhssass pla-

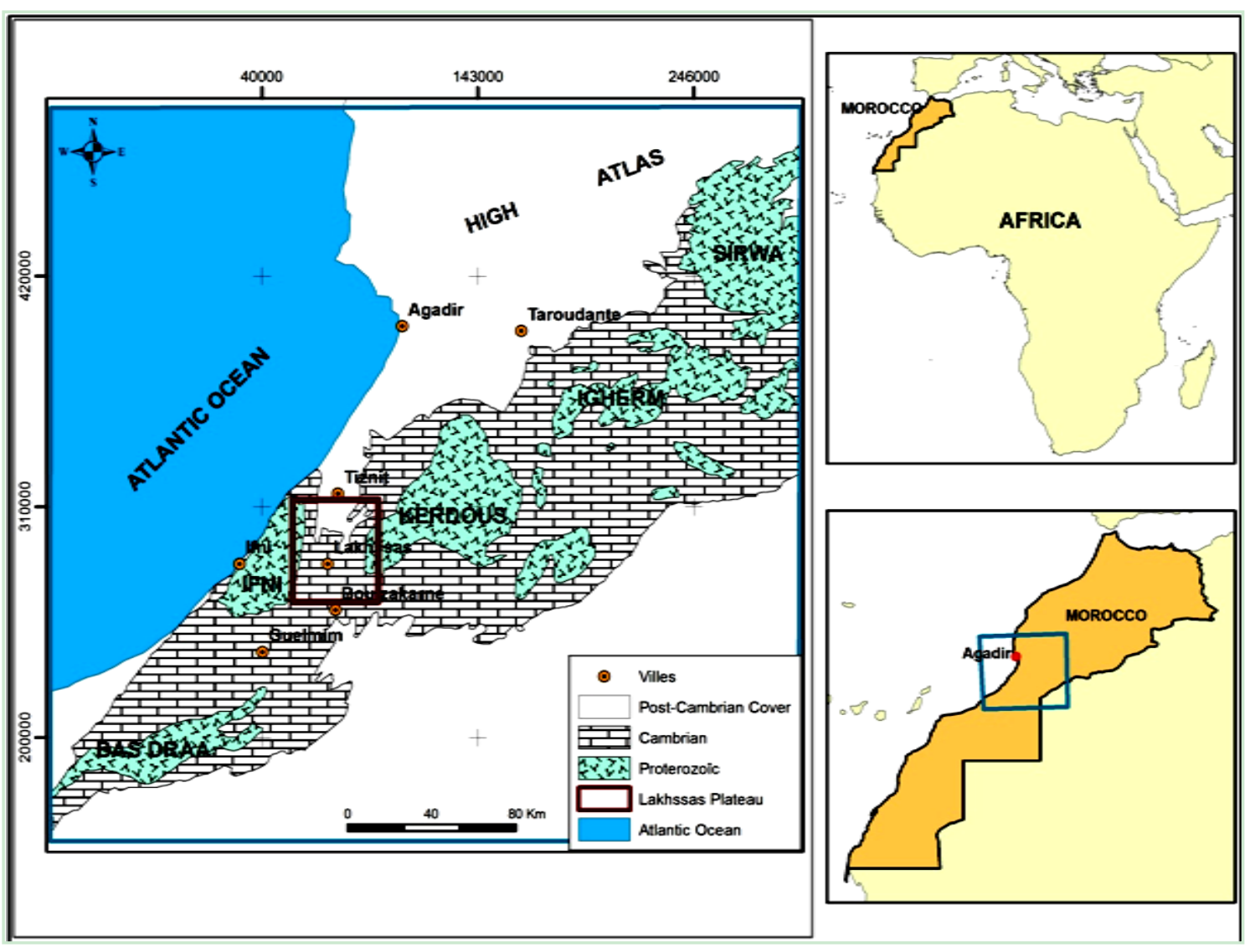

Figure 1. Geographical and geological map of the Anti-Atlas showing the location of Lakhssas plateau. 


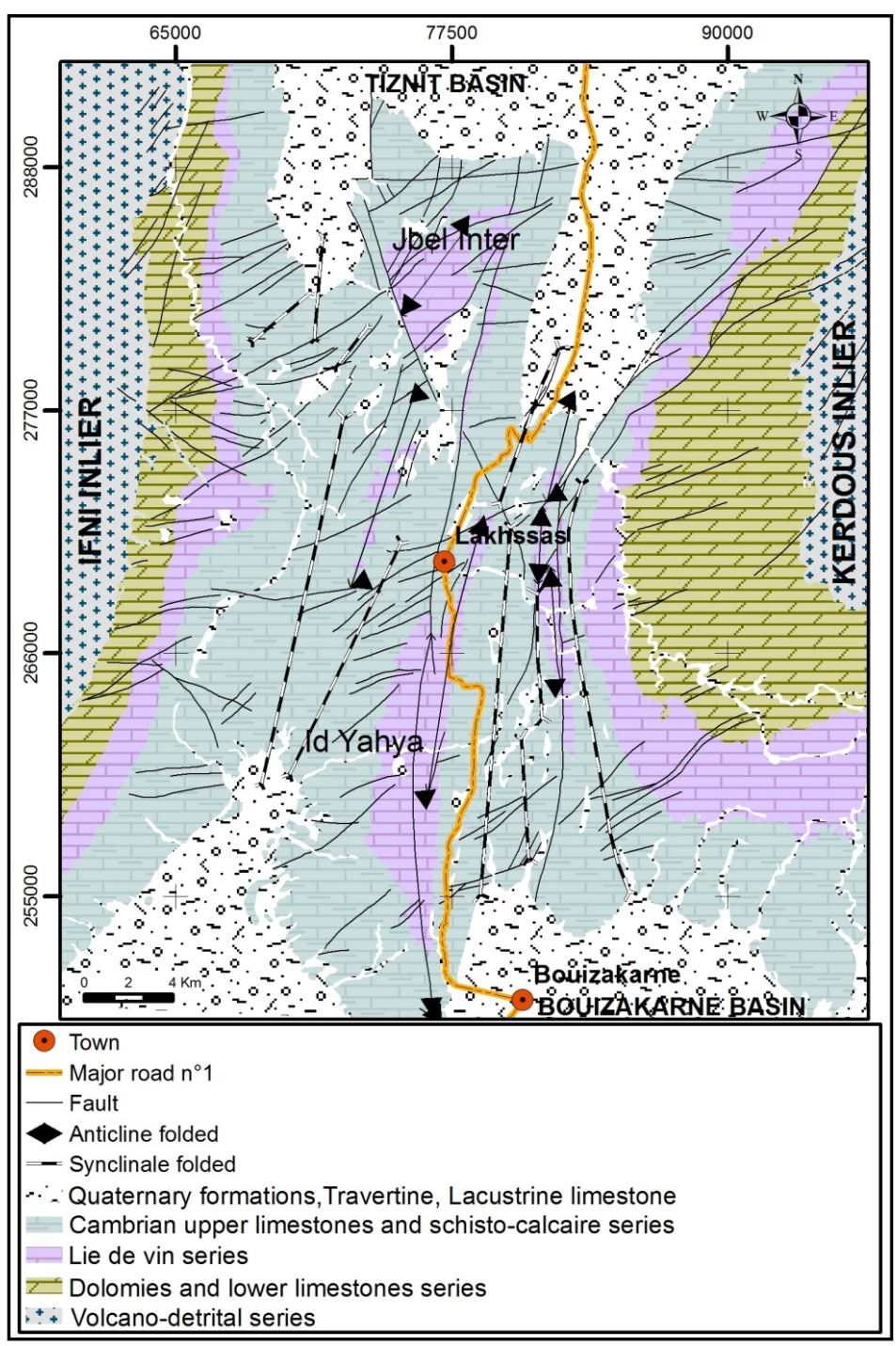

Figure 2. Schematic geological map of Lakhssas plateau 1/100,000.

teau has been up lifted by a shortening WNW-ESE reworking in the cambrian by listric Faults (Figure 3(a)), into reverse to strike-slips [8], where the Ifni and Kerdous blocs motions squeezed the central part of the plateau (Figure 3(b)).

\section{Lakhssass Speleological Spaces Genesis}

\subsection{The Underground Network: Geometry and Features}

This issue concerned a detailed field investigation that involved more than 140 underground sites dispatched over all the studied area, with various inside trends and where $60 \%$ are sinkholes and $40 \%$ are caves [9] (Figure $4(\mathrm{a}))$.

The geometry of the underground network is treated through trend measurements. More than 500 values are plotted using stereographic direction diagram (stereonet software).

According to this diagram, the ENE-WSW direction is clearly the major trend followed by the speleogenesis processes. N-S trend is also a preferred section beside NE-SW. NW-SE to WNW-ESE trend does exist but seems to be less used.

The explanation of this network will be exposed later in this paper, after giving, in the following paragraphs, evidences of several parameters impacts on the underground network genesis. 


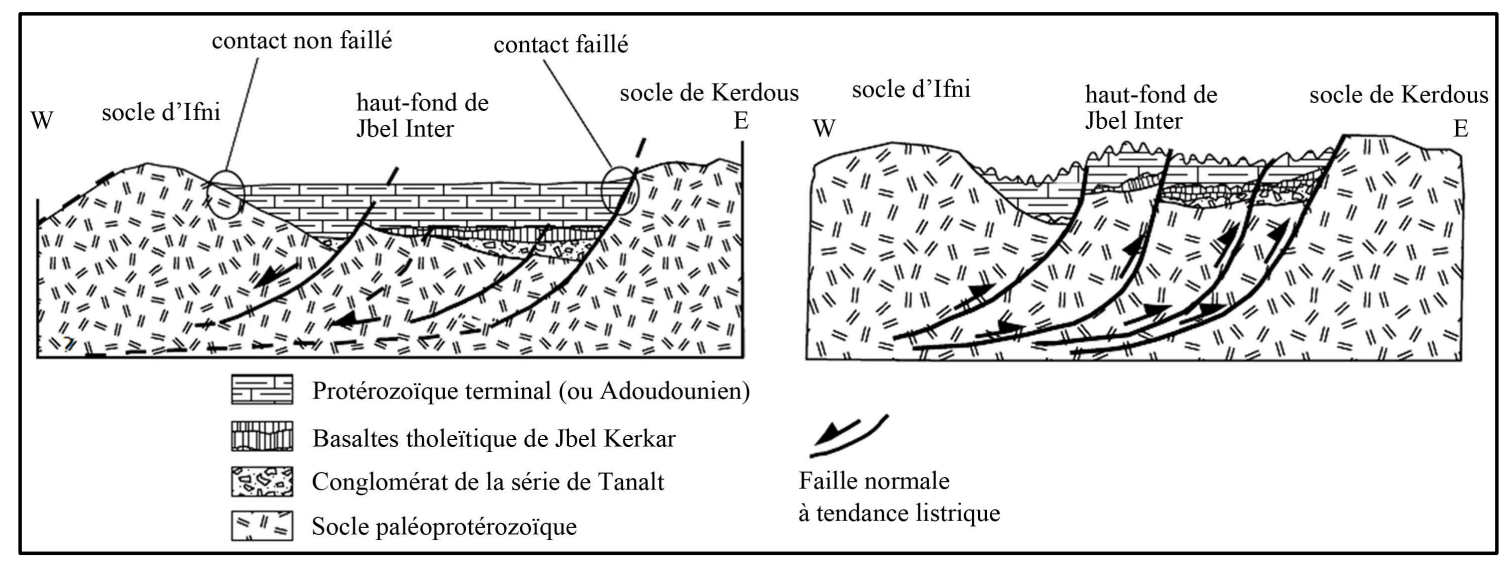

(a)

(b)

Figure 3. Adoudounian deposits corridor in terms of Lakhssas hemigraben open to the west with listric faults system (Belfoul, 2005).

\subsection{Evidences of Tectonic Control}

To achieve this purpose, several stereographic diagrams are established to represent the directions the tectonic structures (major fractures, joints, strike slips and fold axis), then compiled with the underground network geometry to fixe if there is any kind of relationship. To quantify the measurement over the study area, both field and map data [10]-[13] are used (Figure 4).

\subsubsection{Faults and Joints}

Joints and faults play different roles in controlling karst distribution, depending on their relative spatial dimensions and characteristics (length, width, surface area and roughness, opening, etc.), on their frequency and on their intersections with other joints sets [14]-[17].

The stereographic analysis of faults from map and field data using Wulffdiagram, shows three main directions (Figure 4(b)): ENE-WSW, N-S, and E-W.

The geometric analysis of joints reveals NE-SW, E-W and another direction NW-SE.

According to those diagrams, fractures trends (Figure 4(b) 1) are widely well represented in the underground network (Figure 4(b) 3) with ENE-WSW as the main direction and the N-S as a secondary one.

Joints geometry is relatively less represented into the underground network. N-S and NE-SW trend exist but the NW-SE seems not a preferred underground trend.

\subsubsection{Folded and Foliated Structures}

Lakhssas plateau is mainly structured by more or less wide anticlines that spread from Jbel Inter at north and the Id Yahia area at south, with the narrow synclines at its sides.

These folds are often with (Figure 4(c)): a lengths from a few kilometers to a few cms, N-S direction, subvertical axial planes, low axial plunge (to the north or to the south), isopach folds type 1b [18], sometimes evolving to type 2 isoclinal folds, hinges highly stretched in the foliation planes (total transposition S0 (stratification plane) into S1 (cleavage plane)).

These structures (Figure 4) concentrated generally along major submeridional faults so that cleavage is itself submeridional with subvertical to vertical dip. The directional concordance between the cleavage and the folds axis is due to the almost vertical plans flattening.

The compilation of these structures with the cartographic underground spaces shows a remarkable concordance. According to the map in (Figure 4), it seems that the best link coincides with the synclinal structures. Figure 4 provides some additional information, folds and cleavages trends are not enough combined with NWSE underground geometry.

\subsubsection{Interpretation and Synthesis}

Statistical analysis of the elongation and alignment of the underground forms (caves, sinkholes, lapiez, $\cdots$ ) 

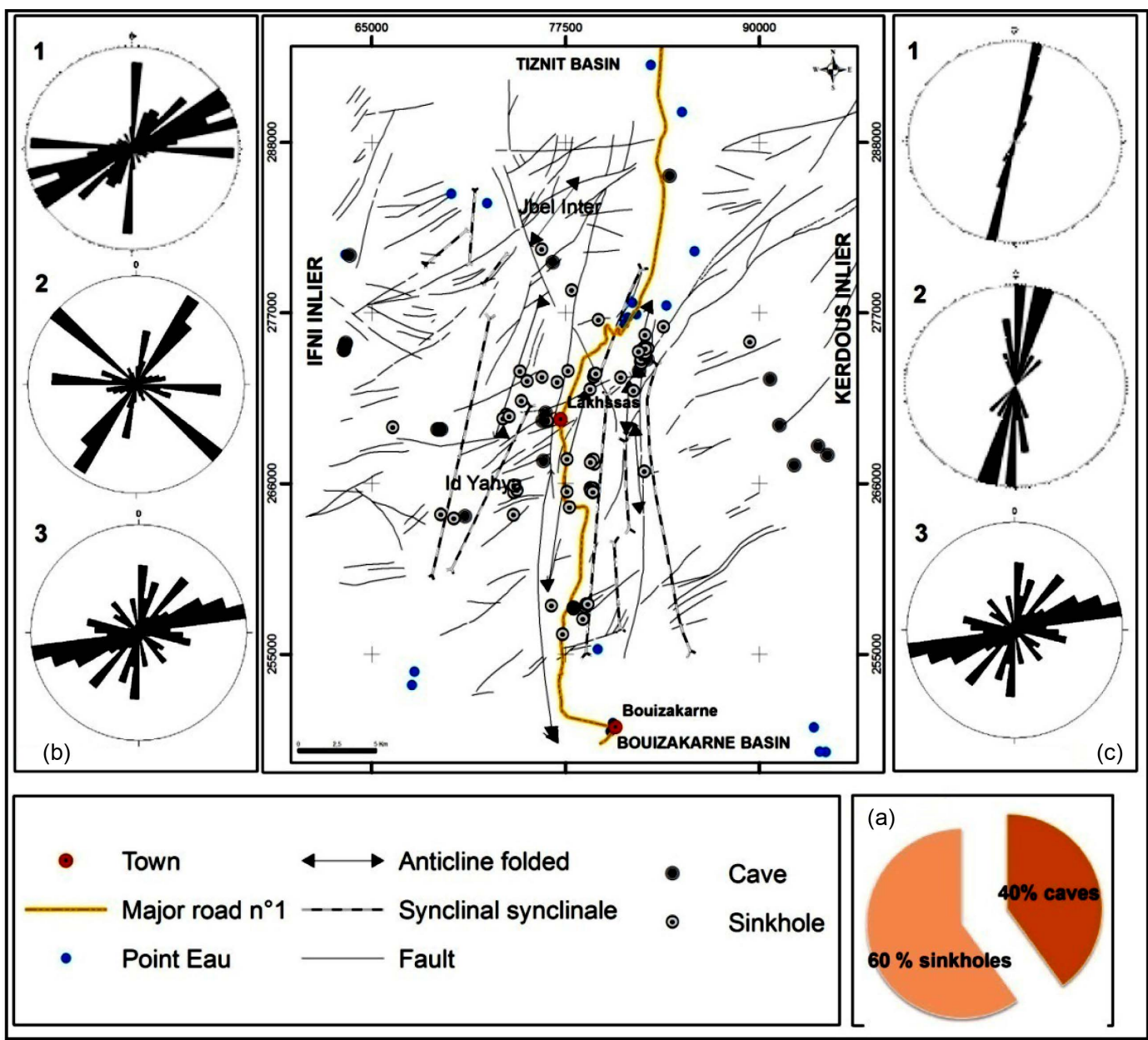

Figure 4. Map representing the various parameters controlling the distribution of underground spaces in the speleological Lakhssas plateau (extracted from Bouizakarn geological map 1/100000). (a) Rates of different underground component. (b) Comparative diagram of main fractures directions from different sources: exokarstic fractures (1) and joints (2) and endokarstic lineaments (3). (c) Comparative diagram of main folded (1) and foliated (2) structures and endokarstic lineaments (3).

listed, shows that the direction of speleological architecture goes with the interference of the faults direction, joints, fold axes and cleavage planes that are: NS, NE-SW, EW and NW-SE but in different rates.

The main direction of underground trend is N-S; this may be explained by the major direction of faults, folds axis and cleavage. The NE-SW and NW-SE directions are due to the conjugate joins that are developed with the $\mathrm{N}$-S major folding. The E-W trend must be connected to the fractures and opening spaces induced by the equatorial main hercynian shortening.

The sinkholes deserve a particular attention. It seems that, in the major cases, their distribution coincides with intersection of fractures or joins so that they present a vertical geometry.

Actually, the density of speleological sites is proportional to that of tectonic structures. Faults, folds and foliation structures are rather favorable to the speleogenesis process.

\subsubsection{Role of Lithologic Composition}

The adoudounian and lower Cambrian age the sedimentary pile is largely dominated by calcareous deposits in various forms (limestone, dolomitic limestone, and dolomite) with some intercalations of sandstones to pelitic nature (Figure 5(a)).

The Quaternary formations are almost outcropping toward the lowland. Slightly thinner in the east but thicker toward the west (Figure 5(b)) [12]. 


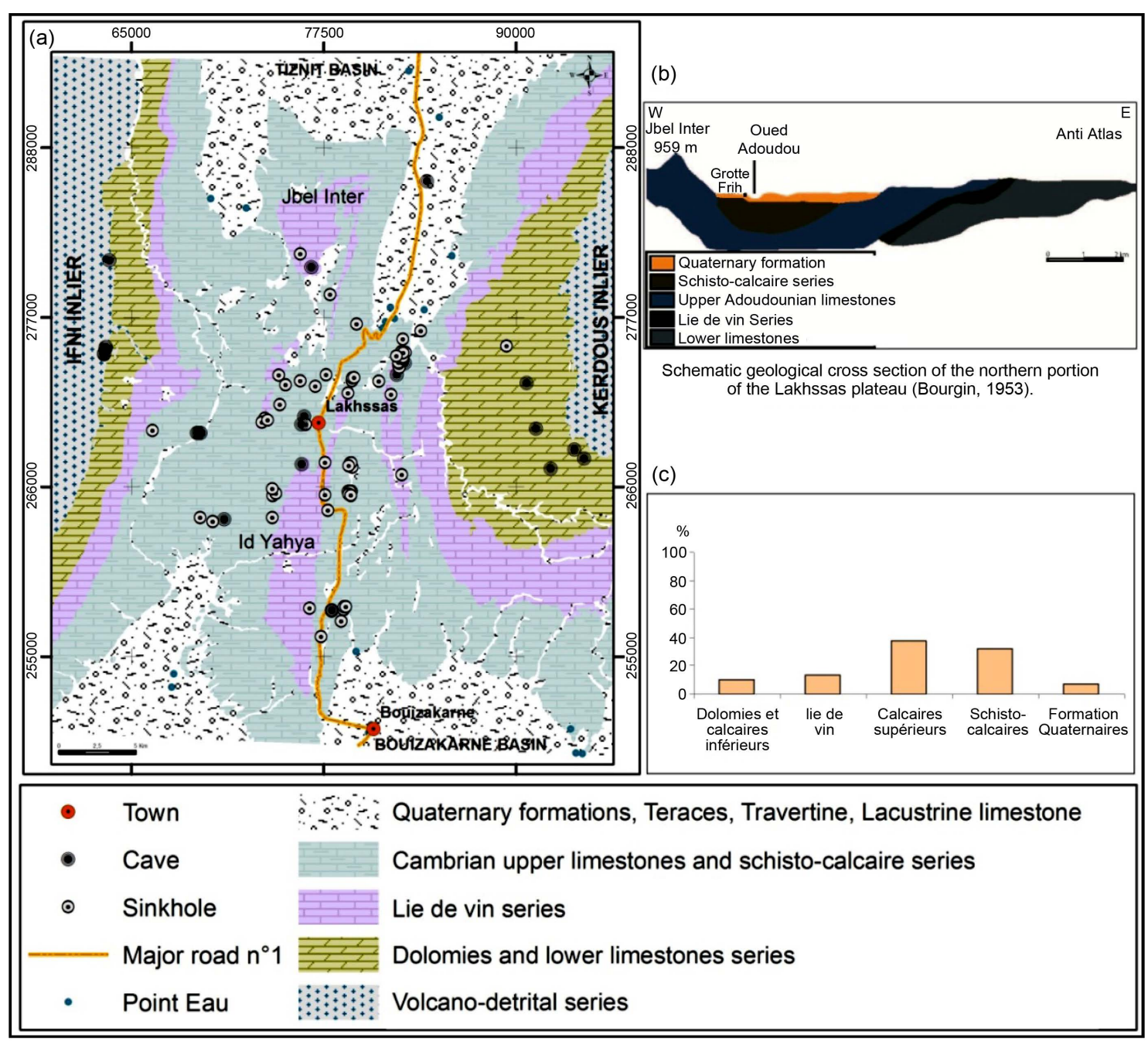

Figure 5. Displays the underground sites in Lakhssass plateau over the lithologic composition and the rate of those speleological units by type of rock.

At the Lakhssas plateau, recent calcareous crusts are very common. They are expressed either into slabs form sonflatsor more dramatically by concretions at the ancient water springs or at the location of river network.

The upshot of this figure is that the Cambrian upper limestones and schisto-calcaire series are the most elected facies to host speleological spaces. Dolomies and lower limestones as well as "lie de vin" series contribute less to this issue. If the first group of limestone rocks is logical to be connected to the speleological network spreading, the second one raises up some troubles (Figure 5(c)). Why dolomies and lower limestones allow a poor part of speleological spaces? This may be explained by the fact that those rocks are stratigraphically, more or less deep so that the serie lie de vin, as it is impermeable, can be a shield that stopped water infiltration to attain lower limestones and dolomies. In this situation, speleological spaces are not well developed at those levels. The rate shown in the (Figure 5) reflects those that are developed when those rocks are outcropping.

Karsts forms can also be found in the villafranchian lakes calcareous of Tiznit lowlands, such as the cave of Frih douar in south of Tadayght. These sites don't show many forms of concretions.

\section{Other Process and Interference of Different Parameters}

\subsection{Topographic and Hydraulic Processes}

To achieve this purpose, we use arcscene as a software application that allows GIS data 3D visualization. The on-working document is giving by "MNT" ("Field Numerical Model”). 
3D analysis extension leads to lay images or vectorial data upon a surface then to extract vectorial entities of a surface to create lines, walls and solids.

3D symbols can be used to give realism in displaying of GIS data and to create animation of high quality. Scenes can be displayed from different angles with vision option. It is also possible to change 3D layers features in order to use transparency or shadows.

This figure show how the hydrographic network is deeply controlled by the fracture field. This can be seen by the main ENE-WSW trend recorded both in the two diagrams (Figure 6(a), Figure 6(b)). Folds axis and foliation trends (Figure 6(c)) are also similar to those of the hydrographic network which means that folds and foliations are guiding the hydrographic flows.

Confronting the hydrographic network to the underground architecture diagrams (Figure 6(d)), it reveals that those trends are closely connected especially with ENE-WSW direction. This led us to input the importance of the hydrographic network in the underground space genesis processes.

Concerning the interaction between hydrographic and underground systems, most of sinkholes and caves are supplied either directly from their entry or by some of their tributaries or even from associated fractures. They therefore, represent spaces where water is infiltrated. This is the case of Ait Taleb Brahim lapiaz in Sidi Hssain district. At this level, around a dozen of deep sinkholes are developed in a surface of about $3 \mathrm{~km}^{2}$. Meteoric waters runoffs are seeping into the caves to feed directly neighbourhood springs and water-sheets as the case of Ifri spring, Tiznit and Bouizakarn plains.

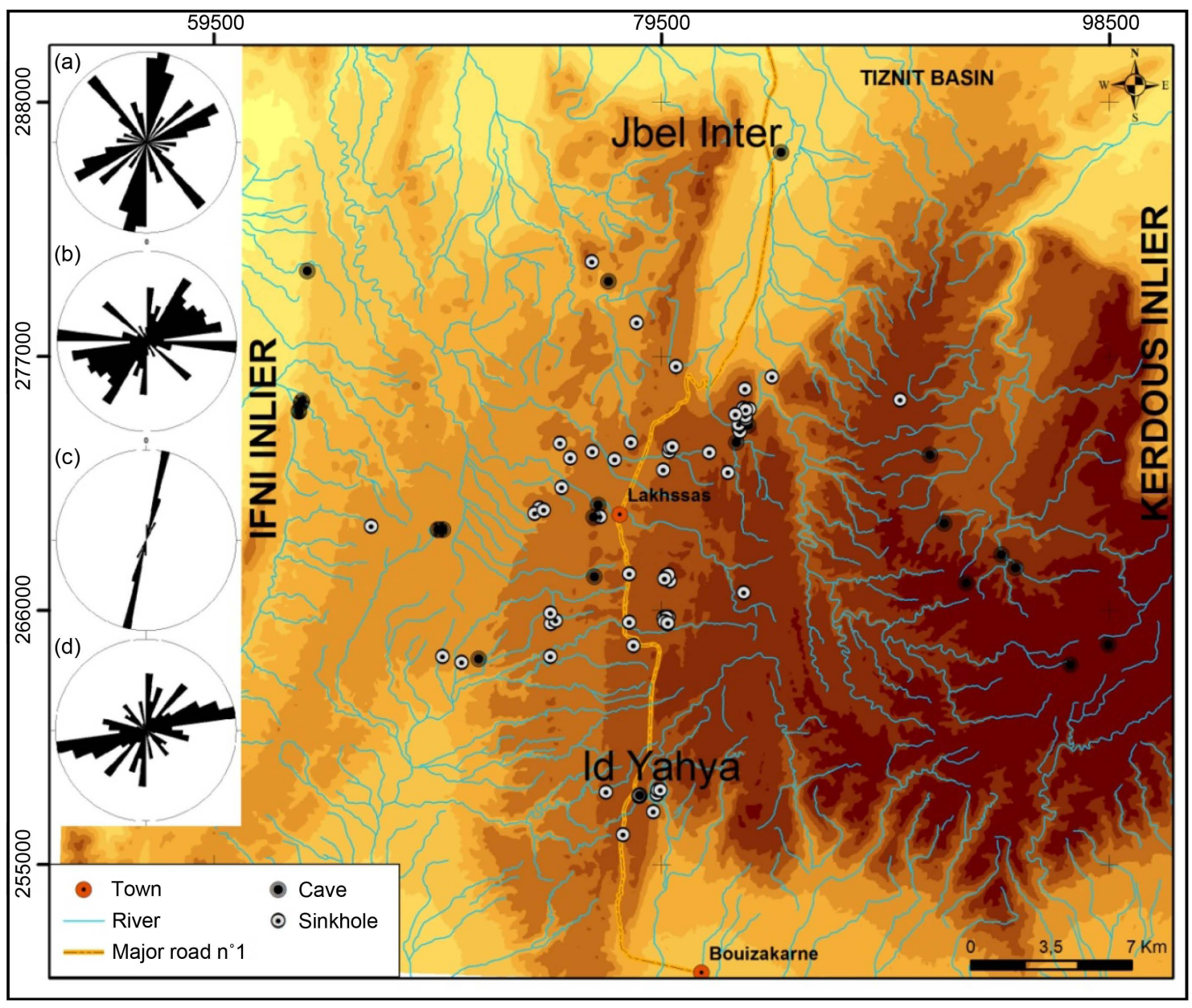

Figure 6. Simplified distribution of speleologic spaces in Lakhssas plateau using MNT and hydrographic network (from topographic map of Bouizakarn, [19]). (a) Trend diagram of hydrographic network cumulative length. (b) Trend diagram of major fractures. (c) Trend diagram of folds and foliations plans. (d) Trend diagram of underround architectural system. 
Hydrographic flow is expressing topographic level changes. The attention was also to check the possible relationship between the speleological network and the altitude. Most of available underground topographic maps show that the altitude gets no impact on the speleology spaces distribution; so caves and sinkholes can be found in Lakhssas plateau whatever the topographic level is (Figure 7).

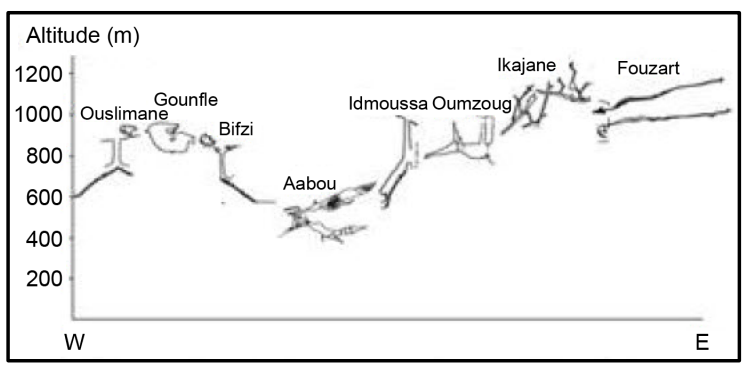

(a)

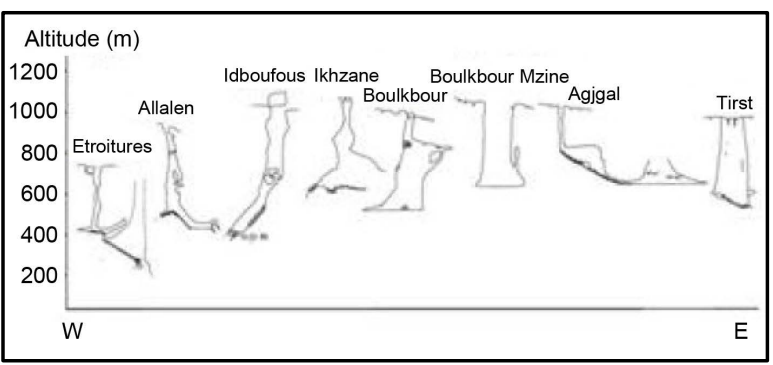

(b)

Figure 7. Sample distribution of Lakhssas Karstic spaces in a function of altitude. (a) Caves Distribution according to altitude in Lakhssas plateau. (b) Sinkhole Distribution according to altitude in Lakhssas plateau.

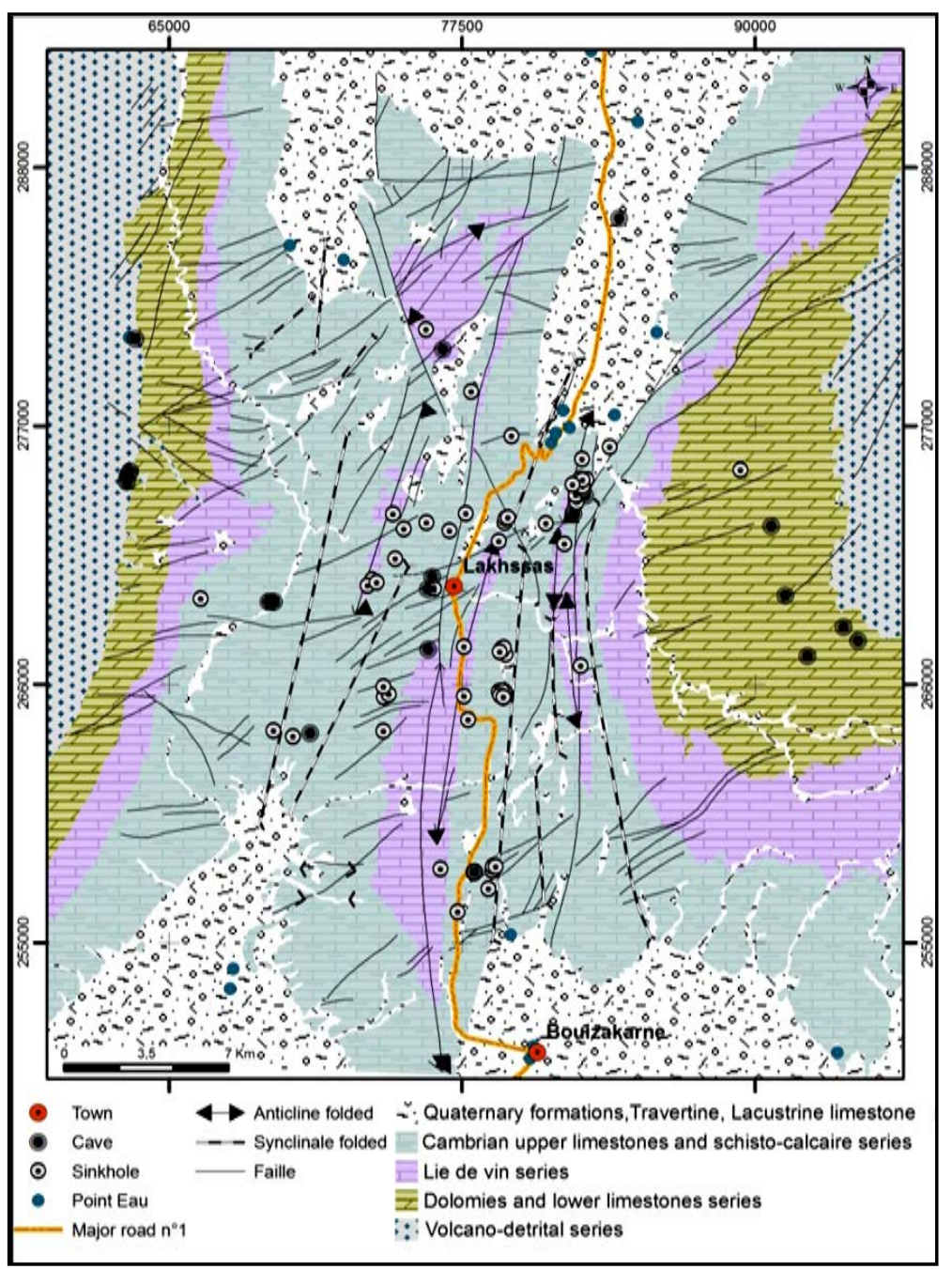

Figure 8. Map representing the various parameters controlling the distribution of underground spaces in the speleological Lakhssas plateau (extracted from Bouizakarn geological map 1/100,000). 


\subsubsection{Climate Processes}

The climate is the main factor affecting the intensity of the karst event. Karst corrosion depends deeply on biological and chemical processes that occur in soil and vegetation covering the rock. In turn, soil and vegetation depend on the amounts of precipitation and temperature fluctuations.

In the case of Lakhssass area and during the Tertiary, the climatic conditions were probably much wetter to promoting the karstogenesis then it became dryer during the Quaternary age [7]. Currently, the arid climate prevailing in those regions doesn't allow the karstogenesis processes except in very limited cases.

\subsubsection{Interference of Various Parameters}

The underground architecture of spaces listed here shows unambiguous connexion with all presented parameters acting individually and in a different rates. Figure 8 shows the distribution of these parameters and the dispersion of speleology devices. It appears clearly that the tectonic lineaments ensure the main control on the underground spaces density [19]. This density is significantly higher when the rock is of calcareous composition. In other words, with limestone composition, tectonic structures prevail as "speleotect" (speleogenesis guidance). This feature is amplified by water circulation either at the surface or at depth. The intensity of fracturing, density and crushing of limestone and dolomite by tectonics, meteoric waters runoffs and groundwater movements, represent mechanically the basic parameters in the karstogenesis in this area.

\section{Conclusions}

The Lakhssas plateau karst developed in limestones and dolomites of the Lower Cambrian and structured by the Hercynian orogeny is an environment favorable to study several scientific disciplines. The structural study of inventoried cavities in the plateau of Lakhssas allows us to highlight the relationship between these karst forms and their genesis and controlling processes and the usefulness of speleothems as markers of neotectonics. Lithology rocks' nature and behavior are also a component of those processes.

The collection of structural data is therefore very important to understand deep karsts systems geometry, particularly where bedding and jointing are able to condition the underground water circulation [20].

The detailed structural analysis allowed defining the relations linking the geometric arrangement of the endokarst system with bedding, jointing, folds and foliations plans. In Lakhssass plateau, the endokarst architecture is miming the exokarstic network with ENE-WSW and N-S to NNE-SSW trends as the main trends controlling the speleogenesis.

The calcareous dolomite composition is also a critical component in the speleogenesis process, beside the meteoric water circulation both at the surface and/or in the depth.

\section{References}

[1] Becker, A., Ferry, M., Monecke, K., Schnellmann, M. and Giardini, D. (2005) Multiarchive Paleoseismic Record of Late Pleistocene and Holocene Strong Earthquakes in Switzerland. Tectonophysics, 400, 153-177. http://dx.doi.org/10.1016/j.tecto.2005.03.001

[2] Gilli, É. (2005) Review on the Use of Natural Cave Speleothems as Palaeoseismic or Neotectonics Indicators. Geoscience, Tectonics p1.8. http://france.elsevier.com/direct/CRAS2A/

[3] Angelova, D., Belfoul, M.A., Bouzid, S. and Faik, F. (2005) Karst and Cave Systems in Bosnek Region (Vitosha Mountain, Bulgaria) and Wintimdouine (High-Atlas Mountain, Morocco). Palaeosismic Phenomena in Karst Terrains in Bulgaria and Morocco. Acta Carsologica, 34, 87-111.

[4] Soulaimani, A. and Bouabdelli, M. (2005) Le plateau de Lakhssas (Anti Atlas Occidental, Maroc): Un graben finiprécambrien réactivé à l’hercynien. Annales de la société géologique du Nord t., II (2 ${ }^{\mathrm{meme}}$ série), 177-180.

[5] Bouchaou, L., Soulaimai, A., Boutaleb, S., Hsissou, Y. and Tagma, T. (2008) Caractéristiques hydrostructurales du plateau karstique de Lakhssas (Anti-Atlas Occidental, Maroc). 1er colloque international de spéléologie Scientifique et touristique, Résumé, Agadir (Maroc) 2008, 21.

[6] Oliva, P. (1977) Karst et structures dans le plateau des Akhssas, L’Anti Atlas occidental-Maroc. Réunion de karstologie, Grenoble, Revue geogr. Alpin XVI 2 et 3.

[7] Hassenforder, B. (1987) La tectonique panafricaine et varisque de l'Anti-Atlas dans le massif de Kerdous (Maroc). Thèse d'état, Université Louis Pasteur, Strasbourg, 249 p.

[8] Belfoul, A. (2005) Cinématique de la déformation hercynienne et géodynamique de la marge NW Gondwana (AntiAtlas Sud-occidental, Sahara Marocain: Zemmour, Ouled Dhlim et Mauritanides septentrionales). Thèse d'Etat, Uni- 
versité Ibn Zohr Agadir, Morocco.

[9] Dubois, A. and Wanaim, A. (2006-2007-2008) Spéléo sur le plateau des Akhssas (Anti-Atlas occidental Maroc). Documents Inédits.

[10] Carte géologique de Bouizakarn 1/100,000. Service de la Cartographie Géologique, MEM, Rabat, Morocco.

[11] Carte géologique de Tiznit 1/100,000. Service de la Cartographie Géologique, MEM, Rabat, Morocco.

[12] Carte topographique de Bouizakarn 1/100,000. Direction de la conservation foncière, Rabat, Morocco.

[13] Belfoul, M.A., Qurtobi, M. and Faik, F. (2001) Impact de la structuration atlasique sur l'architecture interne de la grotte de Win-Timdouine (Haut-Atlas Occidental Marocain). Revue d'Analyse Spatiale, 47-50.

[14] Kiraly, L. (1968) Les élements structuraux et alignement de phénomènes karstiques. Bulletin de la société Neuchateloise de Science Naturale, 127-146.

[15] Kiraly, L. (1969) Anisotropie et hétèrogénéité de la perméabilité dans les calcaires fissurès. Eclogae Geologicae Helvetiae, 62, 613-619.

[16] Kiraly, L. (1975) Rapport sur l'état actuel des conaissances dans le domaine de caractères physiques des roches karstiques. International Union of Geological Sciences, Serie B, Hydrologeology of Karstic Terraines, L.A.H., Paris, 53-67.

[17] Boegli, A. (1980) Endokarst and Karst Hydrology. In: Boegli, A., Ed., Karst Hydrology and Physical Speleology, Springer-Verlag, Berlin, 73-76. http://dx.doi.org/10.1007/978-3-642-67669-7_4

[18] Ramsay, J.G. and Huber, M. (1987) The Techniques of Modern Structural Geology, Vol. 2: Folds and Fractures. Academic Press, London, 445-473.

[19] Wanaim, A., Ezaidi, A., Belfoul, M.A., Bouzid, S., Faik, F., Oudra, M. and Dubois, A. (2008) Rôle des linéaments structuraux dans la distribution cartographique des grottes du plateau de Lakhssass (Anti-Atlas occidental, Maroc). 1er Colloque International de Spéléologie Scientifique et Touristique, Agadir (Maroc) 23-26 Avril 2008, Résumé, 43.

[20] Tognini, P. and Alfrido, B. (2001) Effects of the Structural Setting on Endokarst System Geometry in the Valle del Nosê (Como Lake, Northern Italy). Geolologica Belgica, 4, 197-211. 
Scientific Research Publishing (SCIRP) is one of the largest Open Access journal publishers. It is currently publishing more than 200 open access, online, peer-reviewed journals covering a wide range of academic disciplines. SCIRP serves the worldwide academic communities and contributes to the progress and application of science with its publication.

Other selected journals from SCIRP are listed as below. Submit your manuscript to us via either submit@scirp.org or Online Submission Portal.
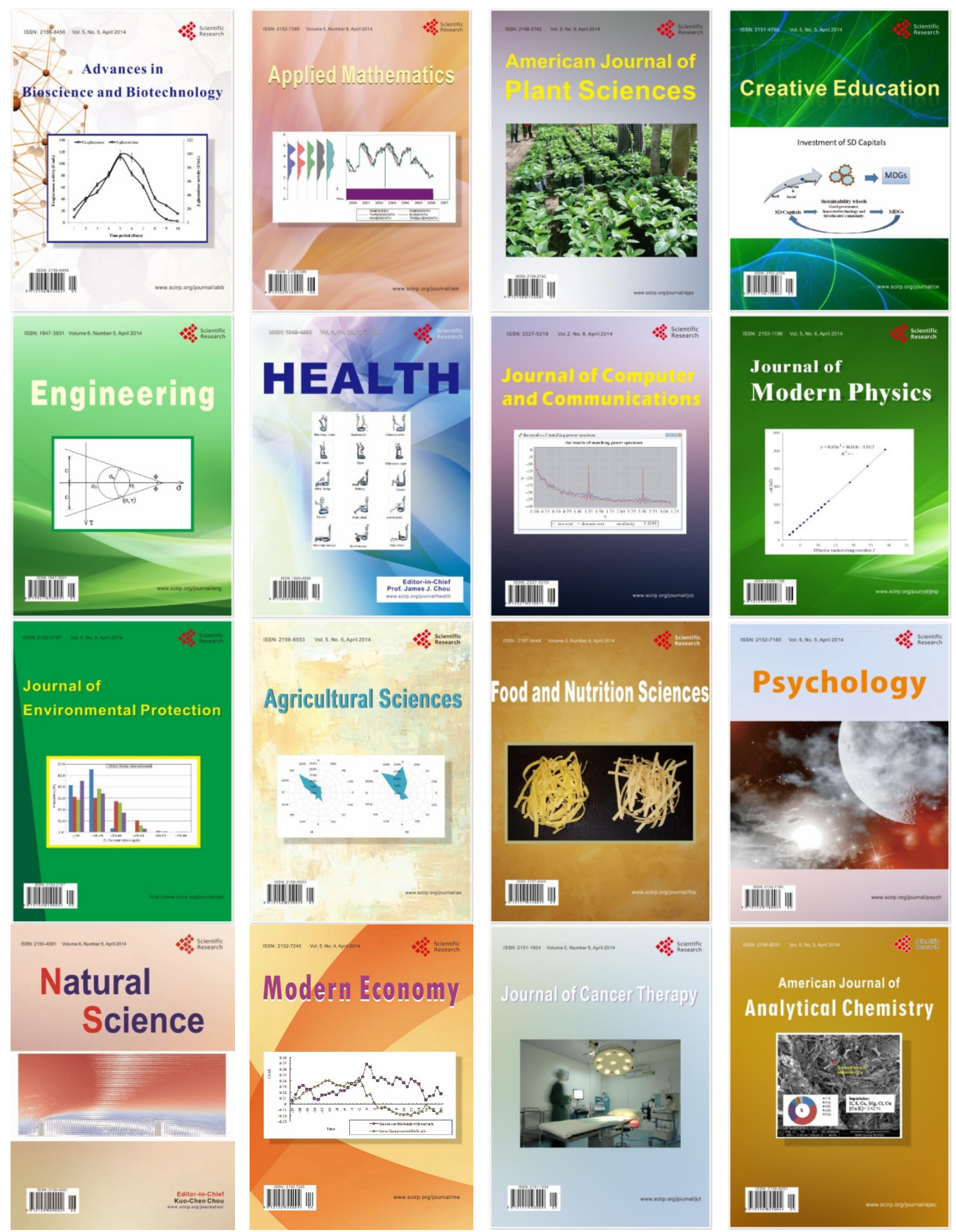